\title{
Chapter 5 \\ Specialists for Crumble Cakes? \\ The German LandFrauen Organizations in Social Innovation, and as Educational, Social, and Political Institutions
}

\section{Laura Suarsana}

The LandFrauen clubs and associations ${ }^{1}$ as contemporary civil society organizations are spread widely across Germany, with a focus on the rural areas. Strongly locally embedded and interconnected nationwide, they address local needs and the interests of women and women in agriculture, and contribute to social and cultural infrastructure and the development of rural regions. They engage in education, knowledge transfer, and political interest representation, and address societal challenges. Despite these activities and their size of about 500,000 members in more than 10,000 local clubs, 22 state associations, and one federal association (DLV e.V., 2020a), the German LandFrauen are to a large part neglected by social sciences and often reduced to "specialists for crumble cakes" (Int. 02, see also Icken, 2002, p. 9; Sawahn 2009, 2012).

In this chapter, I present empirical results on the LandFrauen and illustrate that their activities go far beyond baking, as they, in manifold dimensions, contribute to societal change and the development of rural areas. This case study contributes to the debate on civil society's role in societal change and social innovation: I will discuss how the LandFrauen organizations as an institutional frame enable these activities, which are highly reliant on their diverse and strongly locally rooted base of members. I analyze the diverse practices from the conceptual perspective of social innovation as an approach whose practical dimension is expected to hold particularly high potential for rural areas, which are often affected by infrastructural and socioeconomic deficits and structural weaknesses. The empirical results on the German LandFrauen clubs and associations show that LandFrauen are highly

\footnotetext{
${ }^{1}$ Throughout this chapter, I use $c l u b s$ for the very local organizations with individual members. I use associations for the higher organizational levels with-regularly-organizational members (apart from exceptions with individual memberships also on higher associational levels).
}

\footnotetext{
L. Suarsana $(\bowtie)$

Institute Labour and Economy, University of Bremen, Bremen, Germany

e-mail: laura.suarsana@uni-bremen.de

(C) The Author(s) 2022

J. Glückler et al. (eds.), Knowledge and Civil Society, Knowledge and Space 17, https://doi.org/10.1007/978-3-030-71147-4_5
} 
engaged in initiating change and development in rural Germany by uniquely addressing women's needs through social, cultural, and educational offers: The members' social interactions thereby function as a ground and starting point for further activities that set impulses in local development.

Based on the empirical research, I argue that the LandFrauen activities are, on one hand, integrated into specific local fields and highly adaptive to local needs and interests through the deep integration of the large and diverse base of members in their local villages and rural society. In parallel, they receive support from higher associational levels, providing them with knowledge, ideas, and institutional support. The interwoven local and interregional activities, cooperation, and the exchange of knowledge and ideas, and a broad internal and external networkacross horizontal and vertical levels as well as across geographies-can be highlighted as a key feature of the LandFrauen associations, and as the base of their societal engagement.

This chapter is structured as follows: I will first discuss social innovation as conceptual background and underlying research perspective, followed by a discussion of the LandFrauen as an object of research and an element of associational life in Germany. On this basis, I will derive my research questions and provide an overview on methods, in order to then elaborate my empirical findings on the LandFrauen practices related to societal change, and how they are organized within the associational structure. I reflect upon these results in a discussion of how the discussed practices relate to the concept of social innovation, and of prerequisites that facilitate the explored practices. The chapter closes with a conclusion.

\section{Social Innovation as a Research Perspective}

\section{New Solutions for Society, Unfolding in Practices}

The notion of social innovation is diffuse and contested (Domanski, Howaldt, \& Kaletka, 2020, p. 458; Howaldt \& Schwarz, 2010, pp. 2-3) with regard to its analytical status as well as its use in policy practices (Moulaert, MacCallum, \& Hillier, 2013, p. 13). Key commonality in the variety of understandings of the term is the connection to societal change and the meeting of social problems and needs through new societal solutions (Domanski et al., 2020, pp. 460-462; Howaldt \& Schwarz, 2010; Moulaert \& MacCallum, 2019, p. 31; Mulgan, Tucker, Ali, \& Sanders, 2007, pp. 1, 8; Wendt, 2016, pp. 10-12; Zapf, 1989). Social innovation is related to novelty and innovation as conceptualized by Schumpeter $(1912,1942)$, with processes of diffusion and implementation as relevant criteria (Wendt, 2016, p. 11) ${ }^{2}$ that "a novel idea was put into practice and became institutionalized," or that existing

\footnotetext{
${ }^{2}$ Authors further refer to the process of "creative destruction" as "disruption of existing institutions" (Howaldt \& Schwarz, 2016, p. 58).
} 
elements have been innovatively recombined (Christmann, Ibert, Jessen, \& Walther, 2020, p. 4), or transferred into new contexts or spatial settings (Christmann, 2020a, p. 426).

Moulaert and MacCallum (2019, pp. 32-37) identify two, partly contrasting, paradigms in the research field on social innovation: One they refer to as "AngloAmerican," instrumental and technocratic and related to business and organizational management sciences, its proponents often considering social innovation as complementary to market activity (p. 32). As a second thought line they identify the more interdisciplinary "Euro-Canadian social economy literature," connected to regional development literature and to normative and emancipatory expectations, its proponents relating social innovation to "empowerment, solidarity, socio-political renewal and institutional transformation" (p. 34): They argue that it improves social relations on the micro-level between individuals as well as on the macro-level "between classes and other social groups" (Moulaert et al., 2013, p. 16). Further, it is expected to "collectively [empower] people (especially marginalized people) to act" (Moulaert \& MacCallum, 2019, p. 4). In this view, social innovation unfolds in processes and practices and in joint action from different societal actors "beyond business and government routines" (Brandsen, Evers, Cattacin, \& Zimmer, 2016b, pp. 6-7). It relates to social transformation (Wendt, 2016, p. 13) and includes citizens and larger parts of society as agents of innovation (Domanski et al., 2020).

\section{Social Innovation as Embedded and Contextualized Phenomenon}

Relational conceptualizations of innovation processes discuss the relevance of social interaction, embeddedness, proximity, and institutional context for the creation and transmission of knowledge, understanding the latter as "embodied social practice" (Amin \& Cohendet, 2004, p. 11; Bathelt \& Glückler, 2011; Boschma \& Frenken, 2010; Glückler \& Bathelt, 2017; Rutten, 2017)—which unfolds locally (Asheim \& Gertler, 2005, p. 293), as well as independent of locality, for example, within virtual or temporal knowledge communities (Bathelt, Feldman, \& Kogler, 2011; Bathelt, Malmberg, \& Maskell, 2004; Grabher \& Ibert, 2014; Growe \& Henn, 2020; Lambooy, 2010; Rutten, 2017, p. 159). Researchers have raised communities of practice and epistemic communities as contexts and grounds for learning, knowledge creation, and innovation among groups and collectives (Amin \& Roberts, 2008; Lave \& Wenger, 1991; Müller \& Ibert, 2015, p. 339; Punstein \& Glückler, 2020, pp. 546-548; Wenger, 1998). Accordingly, social innovation is perceived as contextualized "territorial phenomena, embedded in spaces, social relations and institutions that are defined by particular cross-scalar and cross-sectoral dynamics" (Moulaert \& MacCallum, 2019, p. 77) and integrated into "socio-economic structures, institutions and practices" (p. 35). 
Social innovation is always related to collective social action aiming at social change. The institutional perspective sees social innovation as a result of the exchanges and application of knowledge and resources by agents mobilized through legitimization activities. (CajaibaSantana, 2014, p. 43)

Global economic dynamics result in particular localized and spatially concentrated needs, which are addressed within communities through solutions and innovative practices beyond economic concepts. Whereas the addressed problems are place-based, the developed solutions also require and mobilize non-local and trans-local actors, networks, and relations (Moulaert \& MacCallum, 2019, pp. 79-80). Researchers have increasingly discussed social innovation's relevance for local and regional development, its potential for rural areas, often in reference to its local and institutional contextualization (Christmann, 2019, 2020a, 2020b; Christmann et al., 2020; Domanski et al., 2020, p. 455; Füg \& Ibert, 2020; Howaldt \& Schwarz, 2018, pp. 6-7; Richter, 2019; Schermer \& Kroismayr, 2020). Here, local contexts are spaces in which "societal challenges become obvious as concrete social demands and in which problems are tackled by new social practices, often in unlikely collaborations" (Domanski et al., 2020, p. 468), while "institutional embedding - including taking to scale" is perceived as essential factors of success for "socially innovative policies and collective strategies" (Moulaert et al., 2013, p. 18).

\section{The LandFrauen Organizations in German Civil Society and as Object of Research}

By examining the German LandFrauen organizations, I am investigating a rather traditional form of associational life in Germany, with a long history and predecessors stretching to the end of the 19th century (Sawahn, 2009), and a spatial focus in Germany's rural regions. The spectrum of members is nearly entirely female-apart from sponsorship and honorary memberships, and some regional exceptions. ${ }^{3}$ The largest share of members is above 60 (Suarsana, 2017; Int. 01-18). The general organizational goal is

... more justice and equal opportunities for women who are at home in rural areas. This includes the perception and recognition of achievements and equal participation of rural women in work and family, in society and politics, in education, economy, and culture. (DLV e.V., 2020b, own transl.)

In this context, the LandFrauen are involved in diverse activities on all geographic and associational levels, which are linked horizontally and vertically through exchange and cooperation, such as in committees, cooperation, and common events (DLV e.V., 2020a, pp. 23-36; Suarsana, 2017; see Fig. 5.1). More than 10,000 local clubs and the 437 district and 22 state associations are an active

\footnotetext{
${ }^{3}$ Such as in Brandenburg, where also men can become regular members (own research).
} 


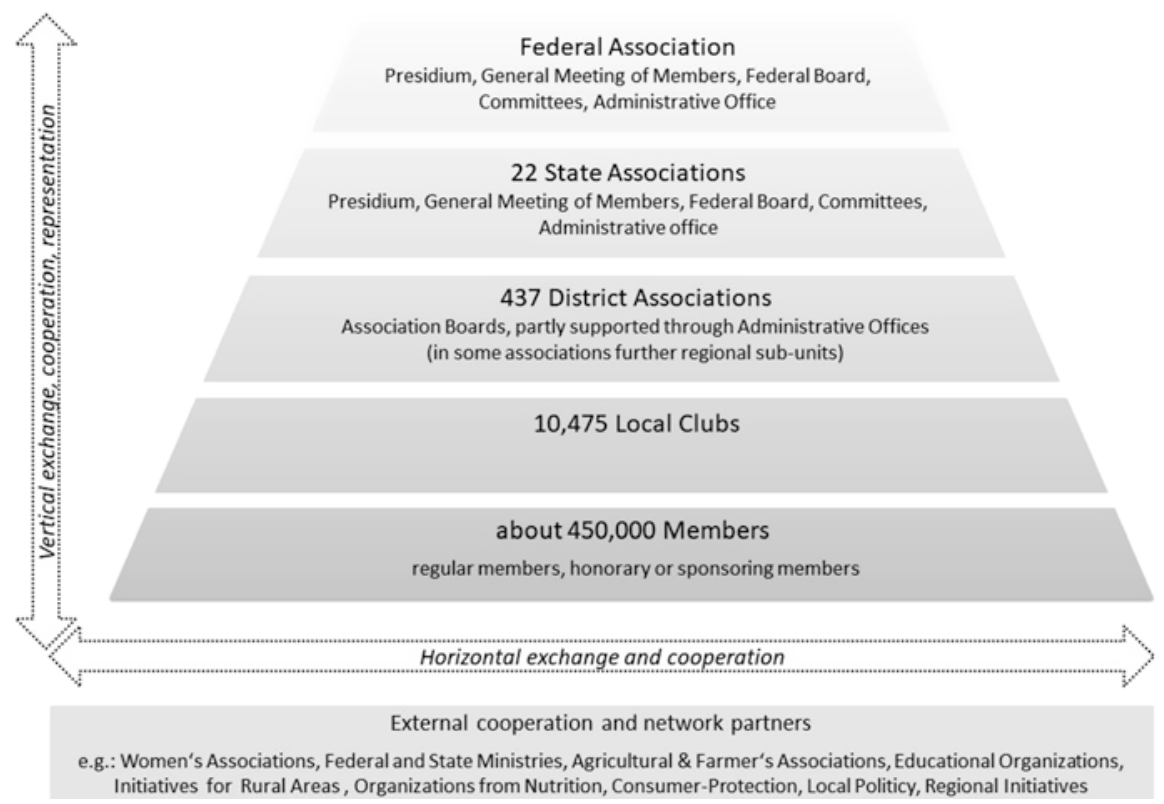

Fig. 5.1 The German LandFrauen associations' organizational structure. Based upon Suarsana (2017, p. 532). Organizational Data and information on cooperation and network partners: DLV 2020a, pp. 24-28

element of associational life in Germany, which since 2016 in total comprise more than 600,000 registered associations as the "dominant legal form" of German civil society-that structures, as well as it is based on, civic engagement (Priemer, Krimmer, \& Labigne, 2017, p. 5). The organizations are broadly represented in external boards, directorates, and committees, such as the German Women's Council and Agricultural Associations, and in various ways cooperate with partners from politics or the fields of education, agriculture, nutrition, and consumer protection, as well as within local or regional policy or regional development initiatives (DLV e.V., 2020a, pp. 24-26, Suarsana, 2017).

Research on the German LandFrauen has so far mostly focussed on their roots and history (Bridenthal, 1994; Helmle, 2009; Krieg, 1999; Sawahn, 2009, 2012; Schwarz, 1990). As contemporary organizations of German civil society, they can be considered as somehow "hidden figures" that only to a small degree are subject of discussion in the social sciences. Scholars have included them in broader analyses of the German associational landscape, women's and agricultural networks, and lobby organizations (e.g., Biegler, 2001; Icken, 2002, p. 9; Rudolph \& Schirmer, 2004, p. 145). As associations, they can be expected to play essential roles in building social capital and contributing to social cohesion (Putnam, 2000), serving as spaces of political socialization and schools of democracy, a "link between microand macro-levels and an integrative element for state and society" (Zimmer, 2007, p. 88, own transl.). In this, they "promise other ways of getting things done, from 
supporting pub[1]ic spheres and providing representation to cultivating the virtues of citizens and providing alternative forms of governance" (Warren, 2001, p. 3). Suarsana (2017) highlights the relevance of the German LandFrauen organizations as an element of rural civil society and regional development. Their role in rural areas is discussed as a "driving force of village development" (Rosa-LuxemburgStiftung, 2005) in their addressing of "basic questions of rural development", in their spectrum of members and broad representation of women in rural areas (Krambach, 2005, pp. 5-6), in their functions as local multipliers as a potential for "the economic, social, and cultural development in the country" (pp. 6-8), or as participants of LEADER-projects (Ebeling, 2017). Further, scholars have to a lesser degree included the LandFrauen in studies on adult education (Ambos \& Greubel, 2012; Baumgart, Becker, Borsch, Merre, \& Maas, 2004; Beetz, Bender, \& Haubold, 2018; Kaschuba, 1996), and with regards to their project work in fields such as health (Jackisch et al., 2020), employment (Putzing, 2003), tourism (Kistemann, 2003), and biodiversity (Lütt, 2007).

\section{Method and Research Questions: Analysis of the LandFrauen's Role in Social Change and Innovation}

Based on the above, I perceive social innovation as societal solutions-new concepts or recombinations - that have a procedural component, are related to implementation in practice and collective agency, are based on exchange of knowledge, ${ }^{4}$ occur institutionally, are socially embedded, and are related to processes of transformation, empowerment and mobilization.

My central research focus in this chapter is to explore how the LandFrauen in their activities and engagement contribute to societal development and serve as carriers of social innovation, and how these activities unfold locally and are influenced by the institutional and organizational structure: To what extent do LandFrauen practices and organizations relate to societal change and promote social innovation? To what extent do they relate to processes of empowerment and "reconfigured social relations"? Which organizational and infrastructural prerequisites enable/further the development of societal solutions and social innovation through LandFrauen? In what follows I will illustrate the results of this empirical assessment of the LandFrauen activities and analyze their societal functions in (rural) society.

The empirical basis of this chapter are 18 qualitative interviews, 17 with leading representatives of 22 LandFrauen Associations in total on the federal-state and national level in Germany, as well as with the president of the national LandFrauen association. I conducted interviews with the German LandFrauen Associations in

\footnotetext{
${ }^{4}$ Knowledge thereby understood as in the introductory chapter of the Knowledge and Space volume "Knowledge for Governance" as "human understanding of concrete and abstract phenomena of the world in which we live"; see Glückler, Herrigel, and Handke (2020, p. 4). For a more detailed reflection on knowledge in its relation to space, see Meusburger (2008).
} 
Brandenburg, Bremen, Hamburg, Lower Saxony (Hanover), Lower Saxony (WeserEms), Hesse, Mecklenburg-Western Pomerania, Rhineland, Rhineland-Nassau, Saarland, Saxony, Saxony-Anhalt, Westphalia-Lippe, Thuringia, SchleswigHolstein, Württemberg-Hohenzollern, and with the LandFrauen Group in the Bavarian Farmers' Association.

Most interview partners were, and mostly still are, in parallel to their voluntary or vocational associational work, integrated as active members into their local home club/association. Some are further engaged within the intermediary regional associations, or are elected members of the board of the national association (see Table 5.1). Thus, the interview partners could provide deep insights not only on the higher aggregated associational activities, but also on local clubs' activities. Interviews were conducted between June and September 2020 via phone with members of the president boards and with managing directors of the associations all over Germany, with an average length of 50 minutes.

All interviews were recorded and fully transcribed using the digital transcription service F4 $\mathrm{x}$ and the qualitative text analytical software MAXQDA. Further, all interviews were analyzed following qualitative content analysis (Mayring, 2015). The results of this analysis are presented in the following chapter on findings, and they form the base of argumentation if not stated otherwise. All direct citations were translated from German into English and linguistically smoothed regarding dialect, colloquial language, and non-thematic fillers.

Table 5.1 Interview details

Total number of Interviews:

Organizational structure:

Registered federal association:

Registered federal state associations: ${ }^{\mathrm{a}}$

Federal state associations incorporated into the state's farmer's association:

Interview partners:

President/Chairwoman of the board (honorary):

Managing director (vocational):

Board member/Vice president:

Interview partners represented in the board of the national federal association:

Regional distribution of the interviewed associations (state level):

Associations in Western Germany:

Associations in Eastern Germany:

\section{Representation of members through interviewed associations:}

Total of (paying) members represented:b

Total of (paying) members represented (Eastern Germany)

Total of (paying) members represented (Western Germany):

aFor historical reasons (see Sawahn, 2009), there are 22 federal associations in the 16 German federal states

${ }^{\mathrm{b}}$ Membership data from DLV e.V. (2019, p. 42)

Note. Source: Design by author 
Further, I conducted participatory observation during the nationwide LandFrauen Days that took place in Erfurt in 2016 and in Ludwigshafen in 2018 with 5,000 and 3,000 participants, events that are organized by the German association for all members of the LandFrauen clubs and associations in Germany. I also draw on primary sources, such as the websites and annual reports of the LandFrauen associations.

\section{Findings: LandFrauen Organizations and Practices in Societal Change and Social Innovation}

\section{Diversity, Geography, and Local Contextualization of the LandFrauen Organizations and Activities}

The associations and clubs differ highly across Germany. ${ }^{5}$ The interviews revealed large differences and different foci of activities, although I could identify a number of core activities throughout all interviews that relate to the general goals of addressing and representing the interests of women, families in rural areas, and specifically women in agriculture, engaging for good conditions of living in rural areas.

As key characteristics of the LandFrauen organizations, several interviewees highlighted the wide range of members, which includes women across all professions, generations, confessions, political affiliations, and social classes, which they attributed to bridging societal functions. They thereby named the overall diversity across regions and members as a quality of the organizational structure. Each club ${ }^{6}$ develops an annual program following the interests and perceived local needs of the local members. Local social activities and regularly organized meetings thereby form the ground for a broad range of further educational and also political activities on local as well as higher associational levels. Vice versa, higher associational levels influence local club activities through setting lead or annual topics, suggesting topics or referents for the education programs, or through central and nation- or statewide projects, or further offers addressed to all associational levels.

The breadth of activities across the clubs and associations is reflected in Table 5.2, which lists all activities by number and subject for 2017 (last data available). The largest share of activities relates to the everyday life and interests of the members in fields of health, sports, arts and culture, consumer policy, home economics, and nutrition. Further activities form a smaller proportion of the overall spectrum, but nevertheless the yearly numbers range into several thousands. These include work for the common good and social work, activities related to agriculture, societal and economic policy, as well as competence-related activities in the fields of communication, association management, media competence, and IT.

\footnotetext{
${ }^{5}$ Accordingly, the activities and examples illustrated below surely do not apply to all clubs or associations.

${ }^{6}$ As well as the district and federal state associations.
} 
Table 5.2 LandFrauen activities (all associational levels) by subject area in 2017

\begin{tabular}{lcc}
\hline $\begin{array}{l}\text { Events at local, district, state, and federal level by } \\
\text { subject area }\end{array}$ & $\begin{array}{c}\text { Number of } \\
\text { Activities }^{\mathrm{a}}\end{array}$ & $\begin{array}{c}\text { Share of Activities } \\
(\%)\end{array}$ \\
\hline Health, sports & 44,239 & 37.4 \\
Art, culture, creativity & 24,418 & 20.6 \\
Consumer policy, home economics, nutrition & 11,206 & 9.5 \\
Activities for the common good, social work & 8,060 & 6.8 \\
Family, social issues & 6,958 & 5.9 \\
Agriculture, rural area, environment & 5,674 & 4.8 \\
Communication, association management & 5,233 & 4.4 \\
Societal and social policy & 3,714 & 3.1 \\
Media competence, IT & 1,009 & 0.9 \\
Economic policy & 891 & 0.8 \\
Other & 7,009 & 5.9 \\
Total & $\mathbf{1 1 8 , 4 1 1}$ & $\mathbf{1 0 0 . 0}$
\end{tabular}

${ }^{a}$ Data for Bremen not included. No data available in the category Activities for the Common Good, Social Work for Bavaria and Rhine-Hesse. No data available in the category Other for Hamburg, Mecklenburg-Western Pomerania, Rhine-Hesse

Note. Source: Design by author. Data from DLV e.V. (2018, p. 42)

Regarding associational structure and activities, broad differences exist horizontally - across the state and district associations and the local clubs - as well as vertically: The higher associational levels fulfil broader and more political functions than the community-oriented local clubs. Horizontally, differences exist in internal organization as well as with regard to the activities, foci, and goals. The variety of clubs reflects the variety of members (see Table 5.3), and interviewees illustrated the influence of local institutional context and structure (see Cajaiba-Santana, 2014) on the clubs and associations. They referred to the associations' differing statutes and the local clubs' strong autonomy, as well as to the specific local conditions, including social infrastructure-local population, identity of the local members, further associations in the villages, and support from politics and potential partners-and material and public service infrastructure, such as the existence of publicly open space, or premises that can be used for meetings and events. Interviewees raised varying political support across the federal states. They especially described the eastern associations as highly regarded and supported, perceived as "important players," by politicians (Int. 04). In urban settings in which the LandFrauen are also represented, interviewees stated less need for social infrastructure in comparison to peripheral regions. All interview partners considered the identity of local individuals who are board members and/or engaged in coordinating their local club, define topics and set the annual programs, to be highly influential on the local activities.

East and West German LandFrauen organizations differ regarding member structure and their historical background. The eastern associations were founded after German reunification, "more top-down" (Int. 13), with crises and growing unemployment especially in agriculture in the eastern states. The newly founded associations offered support and exchange, and partly functioned as an institutional frame 
Table 5.3 Educational activities of the German LandFrauen organizations in 2019

\begin{tabular}{|c|c|c|c|c|}
\hline $\begin{array}{l}\text { Educational } \\
\text { Format }\end{array}$ & $\begin{array}{c}\text { LandFrauen } \\
\text { Organizations (state } \\
\text { and federal level) }\end{array}$ & $\begin{array}{c}\text { LandFrauen } \\
\text { Associations } \\
\text { (state level) }\end{array}$ & $\begin{array}{c}\text { LandFrauen } \\
\text { Associations } \\
\text { (federal level) }\end{array}$ & $\begin{array}{c}\text { German Adult } \\
\text { Education } \\
\text { Centers }^{\mathrm{a}}\end{array}$ \\
\hline $\begin{array}{l}\text { Courses/ } \\
\text { Seminars: }\end{array}$ & 51,521 & 51,512 & 9 & 523,611 \\
\hline Teaching hours: & 125,444 & 125,252 & 192 & $15,646,263$ \\
\hline $\begin{array}{l}\text { Participants/ } \\
\text { Enrollments: }\end{array}$ & 689,719 & 689,563 & 156 & $5,912,896$ \\
\hline $\begin{array}{l}\text { Lectures/ } \\
\text { Discussion } \\
\text { Events: }\end{array}$ & 19,448 & 19,441 & 7 & n.d. \\
\hline Teaching hours: & 66,038 & 66,001 & 37 & n.d. \\
\hline Participants: & 564,077 & 563,599 & 478 & n.d. \\
\hline $\begin{array}{l}\text { Study Trips/ } \\
\text { Excursions: }\end{array}$ & 10,763 & 10,762 & 1 & 8,204 \\
\hline Days: & 27,519 & 27,518 & 1 & n.d. \\
\hline Participants: & 302,234 & 302,177 & 57 & 174,319 \\
\hline $\begin{array}{l}\text { Exhibitions/ } \\
\text { Markets: }\end{array}$ & 3,991 & 3,990 & 1 & n.d. \\
\hline Days: & 7,681 & 7,671 & 10 & n.d. \\
\hline $\begin{array}{l}\text { Total of } \\
\text { Educational } \\
\text { Events: }\end{array}$ & 85,723 & 85,705 & 18 & $637,701^{b}$ \\
\hline $\begin{array}{l}\text { Total of } \\
\text { Participants/ } \\
\text { Enrollments: }\end{array}$ & $1,556,030$ & $1,555,339$ & 691 & $8,162,146$ \\
\hline
\end{tabular}

a'Latest data available for 873 of total 894 in 2018

${ }^{b}$ Includes contractual measures and individual events not listed above

Note. Source: Data on the LandFrauen organizations (totals re-calculated) from DLV e.V. (2020a, pp. 28-32), adult education center statistics (2018) from Lux (2020, p. 1)

for measures of public employment. In addition, the share of women in agriculture varies, so the extent associations address agricultural issues in their offers accordingly does as well. Institutional structure differs with regard to cooperation with the state farmer's association, ranging from the clubs' and associations' complete independence to close cooperation and organizational integration of the associations as sub-organizations into the farmer's associations. ${ }^{7}$ In Bavaria, LandFrauen membership results exclusively from company-related affiliation to a farm with membership in the farmers' association. In the further state and regional associations, the proportion of women from agriculture was estimated to range between about $10 \%$ to $20 \%{ }^{8}$

\footnotetext{
${ }^{7}$ This is the case in Bavaria, Rhineland-Nassau, and South Baden.

${ }^{8}$ These numbers could only be estimated by the interviewees, as data is not available.
} 
Despite these regional specifics, "goals and interests are similar" (Int. 15), and intense exchange and cooperation occurs within the LandFrauen's broad personal and organizational network.

\title{
Community-Building, Togetherness, and Local Social Embeddedness as a Ground for Further Activities
}

\author{
Community is what women look for and find with us. And our large network that we have \\ throughout Germany is something that really sets us apart. (President, German LandFrauen \\ Association)
}

Interviewees named classic associational activity, the building of social capital (Putnam, 2000) and functions as "social glue" (Int. 12) through social activity, togetherness, community building, and contributions to local village life as core activities on the very local level. According to them, creating opportunities to come together and meet within the community on a regular basis and to exchange about personal as well as local and societal problems ${ }^{9}$ are the very element and heart of the LandFrauen. Through their programs and activities, the LandFrauen create conditions and a context for women and local people to meet, engage in social, creative, or educational activities, and to come together, exchange, and interact socially-for example in choirs, reading clubs, sports courses, or seasonal festivities. In this, they contribute to local social and cultural infrastructure in the villages and to social integration, for example, of elders suffering social isolation or newly moved residents. Further, the institutionalized and formally organized activities are broadly accompanied by informal togetherness and interaction, supporting and "appreciating" (Int. 08) each other, and the provision of neighborhood assistance (Int. 13) and "taking care of each other" in the villages (Int. 09). The individual members' social integration thereby creates a basis for the local club's activities.

This sense of community and togetherness and belonging among LandFrauen on the local level is continued inter-regionally and state- and nationwide, and seems to exist across all geographical and associational levels. This is reflected in wide interaction and formal as well as informal exchange among clubs and associations (see Section 5.4.5). A strong sense of togetherness was also a key observation during the national LandFrauen Days in which I participated: I noted a cheerful and open atmosphere and willingness to communicate, interact, and exchange between the women's groups who arrived from all over Germany. Many of the women I spoke to during the events expressed how much they appreciated the event character and visiting the event together with their local group, as well as meeting further LandFrauen from across the country. In Erfurt, for example, the day ended with the

\footnotetext{
${ }^{9}$ They include infrastructural problems regarding childcare, internet connections, and right-wing populism in peripheral rural regions.
} 
thousands of participating women standing and singing together with the band on stage.

\section{Local Engagement, and Functions as Initiators, Catalysts, or Multipliers in Rural Areas}

Integrated into their social contributions, the LandFrauen address further issues related to the quality of life in rural areas through practical local engagement and project activities with which they handle deficiencies in public service provision and rural infrastructure (Suarsana, 2017). Infrastructure, provision of healthcare, internet, and mobility were named as essential issues necessary to "provide perspectives for families in the rural area" (Int. 14). Hereby, I could identify different functions in their regional activity:

Firstly, as local initiators, LandFrauen often spring into action when local infrastructure is to be shut down. "It starts with a petition and ends with 'we'll run your house in,' or we'll be very pragmatic and tackle the problem on site" (Int. 16). In Lower Saxony, LandFrauen initiated a public mobility bus project (Bürgerbusverein Badbergen e.V., n.d.). In Saxony and Mecklenburg-Western Pomerania, they provide a local kindergarten (LFV Mecklenburg-Vorpommern e.V., 2020). Federal associations, such as in Bavaria, Hesse, and North Rhine-Westphalia, initiated support hotlines for women or people from agriculture as a solution to provide anonymous exchange and support, addressing issues of social isolation in rural areas. In Saxony, for example, the ministers of education and the arts as well as regional television were invited to take part in a bus ride for a second-grade elementary school student from a small rural village in order to highlight the consequence of planned school closings that would lead to very long bus rides for primary school pupils. Secondly, interviewees stated that LandFrauen, with their broad base of female members deeply rooted in the rural society, often function as multipliers in rural areas (Int. 04). Several associations engage for democracy-in Saxony, for example, they educate local democracy consultants. Through campaigns and informational activities, the women mobilize others within the villages/regions. Several interviewees highlighted a sense for practical solutions and life management skills as a capability of the LandFrauen in their local engagement, which they stated makes them "very well recognized, by politics, by the mayors and district administrators" (Int. 09). Interviewees described that local clubs build local partnerships and support the establishment of new connections among further actors within the villages, and as a connecting local institution bring together various groups. Thirdly, LandFrauen can be attributed catalyst or supporting functions in external projects or in joint activities - with further partners, such as from local civil society, administration, or politics - that meet local needs and problems or help shape the local public space. In Schleswig-Holstein, for example, LandFrauen support Market Meeting Places, initiated by the federal state of Schleswig-Holstein (Markt-Treff 
Schleswig-Holstein, n.d.). Cooperative projects are partly publicly funded, and activities are often integrated into regional development initiatives such as LEADER $^{10}$ (Ebeling, 2017).

\section{LandFrauen as Institutional Frame and Social Spaces for Learning, Education, and Knowledge Diffusion in Rural Areas}

\section{Central and de-central coordinated education activities}

Activities of knowledge dissemination occur on every associational level. The local clubs, district associations, as well as federal associations pursue manifold decentral as well as joint or centrally organized educational activities. They offer courses, lectures, workshops, and informational events, in order to "bring knowledge and education into the country"-with course education as a "key activity for the state association," as well as through the local associations on site, which "have this educational mandate in addition to their social issues and being involved in the village structures" (Int. 07). In this, education is brought into peripheral areas where further structures and offers in adult education do not exist. While "in cities, women visit adult education centers to further educate themselves", they "stay in the village structures" (Int. 07) and thus provide locally specific offers.

In total, in 2019 more than 50,000 courses and seminars were conducted, 19,500 discussion events, and more than 10,000 educational trips or excursions (Table 5.3), with altogether 1.5 million enrolled participants. ${ }^{11}$ In comparison, the 873 adult education centers in Germany offered a total of 637,701 educational events in 2018, with 532,611 courses and 8,204 study trips (Lux, 2020, p. 1).

In their local offers and their annual programs, the local clubs can rely on offerings and inspiration from higher associational levels: State associations offer topics and internal and external speakers that the local clubs can draw on-partly financially supported through the state association. Many activities, selected educational fields, activities, and course offerings are highly locally specific and organized by the local clubs autonomously and independently from higher associational levels. On higher association levels, the selection of programs and topics is based on decision processes within the boards and committees, including the feedback, expressions of interest, and perceived needs and problems from lower associational levels. Joint projects across the associational levels are partly financed by federal and state ministries or/and supported through further partners. In some federal states, such as Baden-Württemberg and Bavaria, educational activity is carried out through specially set up educational facilities (Bildungswerke), which

\footnotetext{
10 "In two-thirds of all 15 regional action groups in [federal state], a LandFrau has a seat" (Int. 06).

${ }^{11}$ Participants counted by enrollment, not by participant identity-thus double counting may occur.
} 
as organizational entities receive governmental funding. In part, educational activity is integrated into nationwide programs or projects, coordinated by the federal association.

Educational activities are often based on the training of multipliers who then share their knowledge on the lower associational levels, in the respective regions, or within local clubs. Regional or local specialists are trained as multipliers in central levels and then "disseminate knowledge" (Int. 16) or offer coaching and support in their respective regions, for topics such as digitalization, nutrition, consumer protection, and agriculture-related issues.

Many educational activities relate to "everyday skills" (Int. 02): “[n]ew knowledge ... relevant for everyday life" (Int. 07). This includes informing on issues like powers of attorney, care, criminal prevention, insurance, law, pension notices, and rent, as well as nutrition, cooking, or gardening. Educational and societal topics are addressed in a way suited to the target group of women in rural areas. Complementary to their local, regional, and national engagement, the federal association as well as the state associations of Baden-Württemberg and Bavaria also disseminate knowledge in international development work, for example, providing agricultural training and support as well as female empowerment in Kenya and Ghana.

\section{Addressing contemporary societal challenges}

Educational offers, informational events, and campaigns, especially of the federal and state associations, address broader contemporary societal problems and "promote such new topics" (Int. 07) as sustainability and avoidance of food and plastic waste. "We try to take up socially relevant topics and deal with them in such a way that they are transported down to the local clubs and the members" (Int. 07). From there, issues are spread further within the rural population and through the members' personal networks.

In cooperation with state medical associations, health insurances, or universities, LandFrauen disseminate knowledge on new medical developments and engage to prevent myocardial infarction, breast cancer, hearing problems amongst the elderly and children, or injuries through falls. Digitalization, the usage of modern digital media and communication technology and how to communicate via the new media, is broadly addressed in many associations and also within projects of the national association. LandFrauen have implemented several projects that provide training and seminars, especially for elderly women, in topics such as the use of tablets, smartphones, and new media. In Baden-Württemberg, for example, Senior Technology Ambassadors are trained (LFV Württemberg-Baden e.V., 2020b). In Schleswig-Holstein, the project e-LandFrauen provides computer education. Associations have set digitalization as leading themes for several years, through initiatives such as Baden-Württemberg's Digital without limits!? (LFV WürttembergBaden e.V., 2020a) and Württemberg-Hohenzollern's LandFrauen 4.0, in which the associations bring digitalization-related knowledge to its members and inform them about the potentials, as well as risks, of digital technology. Reacting to the Corona 
pandemic, many associations have offered courses for the local boards on how to hold online seminars and organize online meetings. Several clubs further engage in the external nationwide project digital neighborhoods, which "came from the federal level" and has been "very well accepted" on the district level (Int. 03).

This image, the LandFrauen always bake cakes and knit and crochet and sew. Yes, because we can. But we are also open to topics such as dealing with PCs, dealing with tablets, dealing with telemedicine. We have just started a new qualification of digital mentors. In cooperation with a Department of the Ministry of Energy and Agriculture. . . And these LandFrauen, six to eight, are trained to use smartphones and tablets over several days. And they then go back as multipliers to the LandFrauen associations, to their clubs, to make their older women fit in this. (Int. 07)

Further, central activity on the federal, state, and also district and local levels centers around education in the field of nutrition and the origins of food, and in consumer education and engaging in consumer-producer dialogue. Apart from external activities, such as in schools or kindergartens, this also includes internal activities to build understanding and appreciation among the members (Int. 04).

\section{Preservation, dissemination, and recombination of "traditional" knowledge}

LandFrauen engage in, disseminate, and contribute to the preservation of local, historical, ${ }^{12}$ and traditional knowledge and pass it within their institutional and social structure. They engage in activities related to regional customs such as knotting carpets, spinning wool, crocheting, and speaking in dialect, such as Plattdeutsch (Low German)_- "many things from harvest festivals to traditional costume groups, folk dance groups to Easter fountain festivals" (Int. 16). Members disseminate related knowledge in the course and event program, partly coordinated on the state associational level, but also intensively carried out autonomously by members at the local level: "The women want that and organize it for themselves" (Int. 18). This partly entails recombinations of traditional knowledge. For example, LandFrauen in several, especially eastern, federal states, pursue binding of harvest crowns as a local custom. The necessary knowledge is taught in commonality and transferred in practice as non-codified knowledge, as well as taught explicit in workshops. Thereby, LandFrauen developed new modes of tying as "freestyle harvest crowns" (Int. 02), innovatively reinterpreting traditional practice. Further, LandFrauen utilize tradition-related events to address contemporary issues: "They can bring across political demands wonderfully at such a harvest festival, and the women have understood that you can combine it well to keep the traditional, but to make demands at that point" (President, German LandFrauen Association).

\footnotetext{
${ }^{12}$ LandFrauen archive historical knowledge, such as by "writing down life stories" (Int. 05). In Schleswig-Holstein, the state association established, in cooperation with a museum, an historical archive to document former rural life from a women's perspective (LFV Schleswig-Holstein e.V., 2020). Further, they author or publish books on regional traditions and specialities.
} 


\section{Learning and exchange among the diverse base of members and reaching different societal groups as a source for societal change}

Several interviewees perceived bridging functions through including and addressing the interests of women of all ages, professions, confessions, and political affiliations, and described processes of exchange and relation-building between the individual members. Apart from social integration and creating an understanding of the respective life situations, this leads to learning and transfer of knowledge and experiences. During educational trips and excursions across Germany, LandFrauen organizations create new personal connections among the LandFrauen interregionally, as these often include exchange visits of the district association within the target region.

According to the interview partners, the elder generations above the age of 60 form the major share of members. Aspirations to institutionally integrate a larger number of young women have in recent years proven successful in many associations. Interviewees reported that younger women explicitly address and highly value the elder generation's practical and traditional knowledge, such as crafting, cooking and baking skills, while further highlighting the relevance of the young LandFrauen learning about the life problems of elderly women in rural areas. Vice versa, younger women bring "new and innovative ideas" (Int. 01) into the clubs, provide insights into their generation, and introduce elders, in an informal and open manner, to contemporary societal and technical topics-a development that is as well supported through institutionalized educational offers, such as "combined courses, knitting and computer courses. One teaches using the mouse, and the other teaches how to use the knitting needle" (Int. 16).

\section{Exchange and diffusion of ideas across regions and throughout the associational structure}

Intensive exchange that allows for the diffusion of ideas between the individual members and across regions and associational levels can be highlighted a general characteristic of the LandFrauen organizations. Between all organizational levels, intensive horizontal and vertical communication occurs, as well as cooperation and exchange on the respective ideas, activities, and projects. Several interviewees reported having taken over "sparkling ideas" (Int. 02) from other clubs or associations, and that they actively seek information, knowledge, and ideas from other regions, following a "pragmatic approach. We don't need to reinvent the wheel" (Int. 05).

Exchange occurs, firstly, formally organized within the associational structure. This includes representation in boards, working together in expert groups, committees, and planning days, as well as conferences and meetings on specific topics. At the delegate assembly on the federal level, delegates report positive and successful activities from the respective regions. In addition, at the state level, the local and district associations send representatives to committees for exchange. Activities 
allow for the physical or - especially since the beginning of the Corona pandemic increasingly digital co-presence of representatives or members from the different regions or districts. Neighbor associations are also often invited to events like the LandFrauen Days on the regional or district level. District associations organize visiting tours to each other across regions in Germany, and local clubs organize meetings or share events or courses together. Secondly, this formal exchange is accompanied by informal exchange. Personal contacts overlap formal organizational structures and support the interassociational exchange across regions. Several interviewees reported informal activities of exchange and interaction, based on personal and social relations that have emerged in the course of organized exchange or joint activities.

Organized and informal exchange is supported through several communication channels that allow for further sharing of ideas, good practices, innovative projects, ideas for events and speakers, new concepts, and developed solutions. Associations, clubs, and members receive information on each other's activities through annual programs and reports, newsletters, websites, and further means of digital communication. During the Corona pandemic, internal communication has become increasingly digitalized, and members have developed and spread among the associations new organizational practices and formats to bring women together, such as digital wine tastings, in which women from different regions digitally met and got to know each other (Int. 01).

Several interviewees described an example for the diffusion of ideas within the organizational structure with regards to the Corona pandemic. One association, during lockdown, started sending postcards to the members in order to "keep contact and say, hold on, we are with you" (Int. 17). Across several interviews, I could reconstruct how this idea was started within one association and from there diffused among regions and was copied by several further associations, who, through formal or informal contact channels, had learned about it and took over the concept, as well as partly extended it through further elements.

\footnotetext{
We had a very spontaneous idea to design this postcard during the Corona period. And we had to reorder them three times. And then a friend from Westphalia wrote to me: Man, that is a great idea. I said, just imitate it. And then they copied it in their own way. And now they're doing it in Nassau too, and they want to do it in Saxony too. I say it's wonderful. So of course, you can spread that and join in. (Int. 01)
}

Although this is just a small example, it illustrates the close contact among the LandFrauen representatives, as well as the permeability for idea transmission among the organizations. Further, apart from the internal network as a source of ideas, interviewees named the dense network to other associations and partners as inspiration for ideas and sources of knowledge. 


\section{Advocacy work, Interest Representation, and Setting Public and Political Agenda}

Interest representation, raising topics to the societal and political agenda, and influencing public debate is pursued in different qualities and quantities. "The core task is to demand attractive living conditions in rural areas from politics" (Int. 18). Topics range from equal pay and further gender equality issues to services of general interest, such as digitalization in rural areas. LandFrauen associations can be considered highly relevant in their function to give voice to and represent females in the field of agriculture, as women are strongly underrepresented: In the presidential boards of the farmer's associations, women have a total share of $11.9 \%{ }^{13}$ (18 of in total 151 seats). In the federal association and in five of the 18 state/regional associations, women are not represented on presidential boards at all.

On the local level, interest representation occurs partly and often in a smaller dimension, frequently relating to specific local problems and as reactions to infrastructural deficits or cutbacks regarding topics such as offers of childcare, broadband coverage, or provision of health- and midwifery care. The described activities are oriented towards current problems within the villages. Members identify and name these problems and look for ways to solve them. Interviewees brought up that these activities are often not considered political or "classically feminist" (Int. 16) activities, and that regular club members rather have an "everyday understanding" (Int. 12) of politics. Local communication activity differs highly, as it depends on the voluntary engagement and identity of local board members (Int. 11).

Higher associational levels address broader societal issues in their political work. Activities include communicating LandFrauen demands to politics and range from information campaigns, public relations work and press releases, entering into dialogue with political actors or further nonprofit actors in national and federal ministries, to demonstrations and collection of signatures for petitions, taking positions and communicating political demands to federal and state ministries before elections or legal initiatives, and organizing informational events on women and agricultural issues. For this, the federal association, as well as the state associations, offer support and training to their members (see Section 5.6). The higher associational levels, and increasingly the district and local organizations, engage in social media activity and allow for low-threshold information on their activities and positions. The associations are broadly represented and engaged in external committees and networks, especially in the fields of education, gender equality, nutrition, and agriculture, and are represented in the German Women's Council.

\footnotetext{
${ }^{13}$ Own survey, as per 27.10.2020. Included were the presidents or presidential board of the member associations of the federal farmer's associations as published on the association's websites. For Bavaria, the presidential conference was included.
} 


\section{Mobilization and Empowerment for Politics, Associational Work, and Entrepreneurial Activities}

The LandFrauen's ${ }^{14}$ political engagement-for example, in their city or district councils or as mayors - is supported and promoted throughout the associational structure, for example, through informational events and initiating local discussion rounds or inviting successful female politicians as role models. The federal association and several state associations offer training and qualification in skills such as rhetoric and communication for political and associational work. Apart from motivating women to take up institutionalized functions in political processes, clubs inform and gather LandFrauen in "classic" associational functions as "a pre-political space,", "mobilize at a very low threshold and motivate women to get involved" (Int. 3).

Several associations promote democracy and empower women to engage towards preventing racism and right-wing extremism, to address populism and to engage in politics, for example, in eastern Germany, and in two state associations of LowerSaxony in a joint project Democracy means you!-Are women fairly represented in rural areas? (own transl.).

Further, federal associations and several national associations focus on mobilizing and supporting women with regard to entrepreneurial activities. Offers include vocational training to provide women with knowledge and capabilities to become self-employed or to set up their own businesses. State associations, partly, offer coaching and education, or provide further support through their network, e.g. training women as local guides or ambassadors for regional products. In a nationwide project Selbst ist die Frau [Women do it themselves, own transl.], the federal association initiates networks to support and encourage female founders. Women with start-up experience are trained as start-up coaches and offer workshops on selfemployment (Int. 04). To improve working condition for women in the country, in Lower-Saxony, Hanover, co-working spaces are tested as a means for women to better balance work and family life (Niedersächsischer LandFrauenverband Hannover, 2020). In addition, qualification and vocational training is offered for women in agriculture, and "that they can get their voice heard in local politics, also in the public space" (Int. 16). Moreover, during the national LandFrauen Days in Erfurt (2016) and Ludwigshafen (2018), political mobilization, as well as the support of women, and promoting female entrepreneurship, especially in agriculture, were central elements.

\footnotetext{
${ }^{14}$ One interviewee stated that she knew villages where the combination of political activity and LandFrauen engagement was institutionalized in such a way that the LandFrauen board members were in principle engaged into regional politics (Int. 12).
} 


\section{Discussion: LandFrauen as a Case Example for the Promotion of Social Change Through Civil Society-Practices and Prerequisites}

\section{Practices-The LandFrauen's Role in Social Innovation}

The LandFrauen in their manifold activities are a case example of how civil society contributes to social innovation and can function as an agent of societal changewith new ideas and concepts, political involvement, as well as through practical engagement as initiators, catalysts, or local multipliers. They relate to criteria and expectations towards social innovation as discussed in Section 2:

(1) Firstly, LandFrauen pursue activities related to "satisfaction of needs" as an element of social innovation as stated by Moulaert and MacCallum (2019, p. 4.). Interviewees named various innovative projects and solutions for the improvement of rural areas, or to support women and women in agriculture. They bring together women of all ages, professions, and generations with specific insights into local needs. The large number of women and creative ideas coming together was raised as a ground and "important pool" (Int. 03), to quickly find and implement simple, pragmatic, and often unconventional solutions to challenges and infrastructural deficits in rural areas-for example, "converting a residential property, ... . or enabling a daycare center to be set up temporarily on one's farm, when the local kindergarten closes" (Int. 03).

Thereby, some interviewees did not consider the development of new societal solutions and new knowledge and ideas as key activities or general primary goal of their organizations. They stressed, though, that - as elaborated abovethe LandFrauen organizations often contribute to societal or local solutions through identifying and naming problems and societal needs quite early, and in bringing them into political processes and societal debate: "What defines us is that we pass on information and network with experts" (Int. 18).

(2) Secondly, the LandFrauen have bridging functions in their villages and rural areas and build new relations among actors in their local and political work, and thus contribute to social innovation as "reconfigured social relations" (Moulaert \& MacCallum, 2019, p. 50). Several interviewees stated that LandFrauen function as a "motor" (Int. 02) in the country and take initiative for joint local activities and projects. The interviewees hereby raised the relevance of the LandFrauen as politically neutral intermediates, gathering further partners together through "an associational structure that networks well with others. They are very creative in getting women who have often moved here to be involved" (Int. 05). The federal-state and national LandFrauen associations are integrated into broad networks and cooperation with external partners, as well as they are represented in external political committees, working groups, and in boards of further organizations related to their fields of expertise. Several interviewees named good relations to project partners-locally, as well as on the federal state 
level, such as educational organizations, saving banks, health insurances, as well as further associations and clubs or actors from the philanthropic field (see Chap. 9 by Glückler and Suarsana), ministries, or politicians:

The State Secretary for Digitalization just said he brings digitalization to [the federal state] together with the LandFrauen. Because he also knows what kind of network we have and how many we are. (Int. 01)

(3) Thirdly, in their educational and political activities, as well as in their encouragement and mobilization of women to "speak up" (Int. 11) and engage in local politics or societal debate, LandFrauen (in the local clubs as well as on higher associational and geographical levels) relate to social innovation in the dimension of "empowerment or political mobilization" (Moulaert \& MacCallum, 2019 , p. 4) - be it in single organized events, such as demonstrations for equal pay or for mother's rents, in long-term projects, or in encouraging direct involvement of women in political processes. Their raising awareness on topics like gender equality and the structural disadvantages women face, racism, or ecological issues among elderly and rural women (Int. 02, 04, 11, 18) can be especially highlighted, as these women may be expected to only sparsely involve into the related societal discourses.

\section{Prerequisites-What Facilitates LandFrauen Practices Towards Social Innovation?}

In this second part of the discussion, I address the question how these civil society organizations achieve the illustrated-planned, and unplanned-societal benefits as valuable outcomes, especially for rural areas. I argue that activities mainly depend on two key prerequisites that enable LandFrauen to their activities and creates a ground for the promotion of societal change: Firstly, local contextualizationLandFrauen adapt to local conditions and needs, and activities are shaped and influenced by local and regional conditions and the collective agency of contextualized individuals in the understanding of Cajaiba-Santana (2014, see also Subsection 2). Secondly, in parallel, the clubs and associations as an institutional frame have enabling and structuring functions, with informal, as well as formal cooperation and networks across the horizontal and vertical structure. This institutional embeddedness has been raised as a success factor for social innovation by Moulaert et al. (2013, p. 18).

(1) Local contextualization, the diverse and broad membership base, and the organizational network is a capacity and a ground for local engagement and political work.

The LandFrauen members and representatives and their local voluntary engagement are context-specific, deeply rooted in their local village contexts, and integrated into local fields of actors. A large share of activities unfolds at the very local 
level, with actors adapting the specific needs identified by individual local boards and members. Interviewees named the broad network and the high number of represented women, which the associations reach in their activities, as a strength that makes the associations and clubs multipliers and relevant partners for political and non-state actors, as well as a basis for the diffusion of innovative practices into rural societies. The LandFrauen represent the full diversity of women in rural areas, they are politically neutral, and inter-confessional. Due to their broad and diverse base of members, they have the capacity to jointly develop quick, creative, and pragmatic solutions to local challenges and mobilize local individuals and resources for their implementation. Therefore, interviewees stated, external partners perceive and appreciate LandFrauen as reliable, pragmatic, and influential. Further, the large base of members can function as a source of legitimacy for the associations in their political demands and their taking position in public debate.

The interaction within and across the local clubs and groups of LandFrauen can be considered as "local buzz"-an "information and communication ecology created by face-to-face-contacts, copresence, and colocation" with "intended and unanticipated learning processes in organizational and accidental meetings" supporting the "development of shared values, attitudes and interactive schemes typical for communities of practice" (Bathelt, Malmberg, \& Maskell, 2004 p. 38). As discussed above, these enable the LandFrauen to engage in interactive learning and problem solving (p. 45)—supported through the common goals and interests.

Further, interviewees stated that LandFrauen have a strong and noticed position in political processes - a statement that can be backed by the fact that on the LandFrauen Days I participated, several high-ranking politicians-from Chancellor Angela Merkel to the Federal Minister of Agriculture-personally spoke to the women and stressed their role and importance for rural areas and society. Regarding local activities, interviewees illustrated close relations and good cooperation with various local organizations and partners, for example from politics and administration or the philanthropic field (see Chap. 9 by Glückler and Suarsana).

Interviewees illustrated the relevance of the LandFrauen network as a source of institutionalized support, as well as its quick reaction to societal problems, by the example of voluntary production of face masks during the beginning of the Corona pandemic in places all over Germany, on large scales of often hundreds or thousands. The clubs' and members' local networks organized the distribution in cooperation "with other organizations ... You've seen it spread like a spider's web" (Int. 15).

(2) Institutional embeddedness allows for vertical and horizontal cooperation, exchange, and access to resources across the associational levels and "beyond geography" (Bathelt, Cohendet, Henn, \& Simon, 2017, p. 11).

A broad range of diverse perspectives and individuals are joined through a sense of community and common understandings and practices. In this, the Land Frauen can be considered as institutions, "ongoing and stable patterns of repeated social interaction, based on mutual expectations that owe their existence to purposeful constitution or unintentional emergence" (Glückler \& Bathelt, 2017, p. 121). 
The clubs and associations "stabilize interaction and correlated patterns of behaviour" (Setterfield, 1993, as cited in Bathelt, Cohendet, Henn, \& Simon, 2017, p. 4), and "as collective actors . . . align resources and interests in pursuit of a common goal” (Glückler \& Bathelt, 2017, p. 122).

Despite differences and high heterogeneity, the LandFrauen clubs and associations form a stable organizational context that pre-structures the local, regional, and national common activities and create frameworks for the practices and joint activities of their members and representatives, as well as the cooperation with external partners. The members and representatives are deeply rooted in their local as well as specific associational contexts. In parallel, an often-stated feeling of community, belonging, and social proximity creates the basis for further activities and is also felt on higher geographical/associational levels. This sense of community and the underlying social relations and activities support institutionalized exchange and form the basis for societal engagement and for educational and political work.

The local clubs, socially rooted in the villages and rural society, are integrated into an inter-regional organizational network where ideas, concepts, and knowledge, as well as resources and institutional support are exchanged and diffuse across geographical and associational levels. The underlying and permeable vertical and horizontal organizational structure allows for the quick dissemination of ideas, practices, and knowledge, and to spread information into the rural area. This is supported and supplemented by underlying social ties and informal exchange.

Further, the higher aggregated associational levels, their broad network, allows for the implementation of larger projects, partly government-funded or co-funded by external partners. They create access to external resources and support and provide opportunities for funding, educational offers, as well as they train multipliers that reach out to the specific regions.

Not only the local clubs, but also associations on higher organizational levels benefit from institutional embeddedness and horizontal and vertical connectivity: Through inner-associational representation, formal and informal exchange, and connections among the associational levels, issues and topics are transported from the bottom up into the higher associational levels. From there, "good connections into state politics as well as federal politics" (Int. 16) are used to set agenda in political processes.

In their activities and the local and societal functions, LandFrauen-as well as their clubs and associations as collective actors-can be conceptualized as "key players of socio-spatial change" in the dimensions identified by Gailing and Ibert (2016, p. 391): (1) On the micro-level, as "leaders", they may create a "mood of optimism" among local followers and generate or "initiate demonstration projects" (p. 400). This applies to engaged individual and board members in the local clubs that — as learnt from the interviews - are highly influential on the local activities and offerings. Further, this can be related to the manifold context-specific activities individual LandFrauen conduct to improve their local villages. (2) As intermediaries or 
"boundary spanners" on a meso-level ${ }^{15}$ (pp. 393-394), they mobilize "external, territorial rooted knowledge as well as institutional and cultural resources in favor of a space" (p. 400). Throughout the inner-associational structure, knowledge, ideas, and institutional support are accessible from the higher associational levels as well as from further partners from other regions on the same horizontal level. (3) Further, on a macro-level, "governance-pioneers" are stated to "prepare ways or modes of governance, collective arenas for action, and in changing policy content" (p. 400). This may hold for the LandFrauen associations as collective actors in their interest representation, political work, and lobby activity on the federal-state and national level. In this combination of activities, they may-intentionally or unintentionally - contribute to "transition, creativity, innovation, [and] path creation" (p. 400) and to societal change.

\section{Conclusion}

By the example of the LandFrauen clubs and associations, this chapter has illustrated how civil society practices can relate to social change in rural areas of Germany, and how relational connections to many other partners at local and above local level enable civil society organizations to further social change and social innovation. The results indicate that agents of social innovation need to adapt to local needs, while in parallel, this presents associations with the challenge to align their often centralized structures and goals with the diversity of local challenges and local partners.

The empirics have shown that, although the 10,000 local clubs and regional and federal state associations are highly individual and heterogeneous, they can be attributed relevant roles in social change and social innovation and as educational, social, and political institutions. This case study revealed manifold practices through which the LandFrauen, as an element of German associational life and rural society, contribute to social change and social innovation-as initiators, as supporters, as catalysts in external or joint activities with partners, or as regional multipliers in the diffusion of knowledge, debates, or practices directed towards contemporary societal challenges. Through interest representation, mobilization, and intensively local, as well as nationwide exchange, LandFrauen identify and call attention to problems of rural communities, and jointly develop and implement related ideas and solutions.

Apart from their traditional associational and social functions (Putnam, 2000; Warren, 2001; Zimmer, 2007), the LandFrauen are unique in their spectrum of activities and their engagement for women and the rural spaces in Germany. They provide social, cultural, and educational infrastructure. They bring issues into societal debate and into political process through advocacy and identifying and naming

\footnotetext{
${ }^{15}$ Richter (2019) has identified similar functions for rurally embedded social enterprises, for which he, among further aspects, identifies the re-contextualization of ideas as "embedded intermediaries" and information brokers (pp. 185-186) as key functions.
} 
challenges and problems of women and in rural areas. In this, they contribute to the public sphere (Calhoun, 2011; Habermas, 1962/1989) and set societal and political agenda. They promote societal change as they diffuse contemporary societal debates and solutions, and related knowledge, into rural areas. Through practical local engagement, clubs and associations actively engage to improve rural areas and the situation of women, and through respective projects and activities they implement creative and innovative solutions for rural areas. On higher associational (as well as geographical) levels, representation of interests is a focal activity, whereas the clubs, associations, and their local activities serve as a pre-political space of debate and discussion. They mobilize and empower women as well as represent their interests locally, throughout the federal states, and nationwide. They create awareness in the rural periphery of broader societal and political issues concerning women and the rural areas, and they support female engagement in politics through support and coaching in the field of political and associational work. LandFrauen connect, empower, and mobilize women for political and associational engagement, and they support female (self-)employment.

As prerequisites enabling LandFrauen to pursue their activities, I identified two key characteristics: Firstly, the institutional frame of clubs and associations allows for support, cooperation, and exchange across the vertical and horizontal structure, and provides access to resources and a broad network to external partners. LandFrauen organizations create institutional environments that allow for processes and practices of joint learning, interaction, and the diffusion of knowledge and ideas, as well as providing institutionalized support and encouraging debate and joint activities among the organizations, the local members, and its representatives. The associations thereby fulfil transmitting functions between the local members and higher associational (and geographical levels), as well as representing the members in broader political and societal contexts. The stable organizational structure of clubs and associations - as social and political institutions - are based on the broad representation of their diverse membership base, especially in rural areas, and on the specific horizontal and vertical interwoven organizational structure. They create temporary as well as timely stable and ongoing spaces for learning and exchange, and enable women to engage in practices of social, educational, and political activity, as well as in activity to improve the living conditions in their rural (or urban) surrounding. Secondly, the activities towards social change, especially on the very local level of villages and communities, unfold contextualized on the ground of the broad, diverse, and deeply locally rooted membership base in the rural areas. The local LandFrauen, the individual members and their clubs, are strongly integrated and embedded into local fields of actors and rural society.

In this, the LandFrauen as "key players in socio-spatial change" (Gailing \& Ibert, 2016, p. 391) connect the local rural villages and their female members with women, internal and external partners, and societal developments from outside the local context. On a meso- and macro-level, they enter into political debate and put LandFrauen positions and problems on societal and political agenda. Potential for further research on the LandFrauen may lie in the debate on criteria of success for the implementation of social innovation practices against the background of their 
external relations from a field-oriented perspective (DiMaggio \& Powell, 1983; see also Chap. 9 by Glückler and Suarsana).

Brandsen, Evers, Cattacin, and Zimmer (2016a) stress that social innovations are precarious in that "they are often timely limited and do to a large part not further diffuse out of their local context" (p. 307). This study is limited to the LandFrauen practices towards social change, and their prerequisites. A deeper analysis of the LandFrauen's external relations, and how their ideas, solutions, and practices unfold further among the actors throughout organizational fields, might shed further light on the conditions for the successful implementation of social innovation in (rural) society.

\section{References}

Ambos, I., \& Greubel, S. (2012). Ökonomische Grundbildung für Erwachsene: Themenfeld „Akteurs- und Angebotsanalyse“: Abschlussbericht [Basic economic education for adults: Subject field "Analysis of actors and offers"]. Retrieved from www.die-bonn.de/doks/2012oekonomische-grundbildung-akteurs-und-angebotsanalyse-01.pdf

Amin, A., \& Cohendet, P. (2004). Architectures of knowledge: Firms, capabilities, and communities. Oxford, UK: Oxford University Press.

Amin, A., \& Roberts, J. (2008). Knowing in action: Beyond communities of practice. Research Policy, 37, 353-369. https://doi.org/10.1016/j.respol.2007.11.003

Asheim, B. T., \& Gertler, M. S. (2005). The geography of innovation: Regional innovation systems. In J. Fagerberg, D. C. Mowery, \& R. R. Nelson (Eds.), The Oxford handbook of innovation (pp. 291-317). Oxford, UK: Oxford University Press. https://doi.org/10.1093/oxfor $\mathrm{dhb} / 9780199286805.003 .0011$

Bathelt, H., Cohendet, P., Henn, S., \& Simon, L. (2017). Innovation and knowledge creation: Challenges to the field. In H. Bathelt, P. Cohendet, S. Henn, \& L. Simon (Eds.), The Elgar companion to innovation and knowledge creation (pp. 1-25). Cheltenham: Edward Elgar. https:// doi.org/10.4337/9781782548522.00006

Bathelt, H., Feldman, M. P., \& Kogler, D. F. (2011). Beyond territory: Dynamic geographies of knowledge creation, diffusion, and innovation. Regions and Cities: Vol. 47. Abingdon: Routledge.

Bathelt, H., \& Glückler, J. (2011). The relational economy: Geographies of knowing and learning. Oxford, UK: Oxford University Press. https://doi.org/10.1093/acprof:os obl/9780199587384.001.0001

Bathelt, H., Malmberg, A., \& Maskell, P. (2004). Clusters and knowledge: Local buzz, global pipelines and the process of knowledge creation. Progress in Human Geography, 28(1), 31-56. https://doi.org/10.1191/0309132504ph469oa

Baumgart, E., Becker, U., Borsch, K., Merre, J., \& Maas, I. (2004). Professionalisierung im Ehrenamt und zielgruppenorientierte Weiterbildung: Das Projekt „Lebenslanges Lernen“ im Landfrauenverband Bernkastel-Wittlich [Professionalization in voluntary work and target grouporiented further training: The "Lifelong Learning" project in the Rural Women's association in Bernkastel-Wittlich]. In D. Behrmann, B. Schwarz, \& K. Götz (Eds.), Professionalisierung und Organisationsentwicklung: Optimierung der Rahmenbedingungen des lebenslangen Lernens in der Weiterbildung. Bielefeld: Deutsches Institut für Erwachsenenbildung_Leibniz-Zentrum für Lebenslanges Lernen.

Beetz, S., Bender, P., \& Haubold, F. (2018). Erwachsenenbildung im ländlichen Raum: Ergebnisse der qualitativen Studie „Weiterbildungsbedarf in ländlichen Regionen im Freistaat Sachsen“ [Adult education in rural areas: Results of the qualitative study "Needs for further training in 
rural regions in the Free State of Saxony"]. Edition VHS Aktuell—Beiträge zur Weiterbildung: Vol. 7. Retrieved from https://www.vhs-sachsen.de/fileadmin/user_upload/Dokumente/ Projektdoku_Land_web.pdf

Biegler, D. (2001). Frauenverbände in Deutschland: Entwicklung-Strukturen-politische Einbindung [Women's associations in Germany: Development-structures-political involvement]. Forschung Politikwissenschaft: Vol. 139. Opladen: Leske + Budrich. https://doi. org/10.1007/978-3-322-97540-9

Boschma, R., \& Frenken, K. (2010). The spatial evolution of innovation networks: A proximity perspective. In R. Boschma \& R. Martin (Eds.), The handbook of evolutionary economic geography (pp. 120-135). Cheltenham: Edward Elgar. https://doi.org/10.4337/9781849806497.00012

Brandsen, T., Evers, A., Cattacin, S., \& Zimmer, A. (2016a). The good, the bad and the ugly in social innovation. In T. Brandsen, S. Cattacin, A. Evers, \& A. Zimmer (Eds.), Social innovations in the urban context (pp. 303-310). Cham: Springer. https://doi.org/10.1007/978-3-319-21551-8_25

Brandsen, T., Evers, A., Cattacin, S., \& Zimmer, A. (2016b). Social innovation: A sympathetic and critical interpretation. In T. Brandsen, S. Cattacin, A. Evers, \& A. Zimmer (Eds.), Social innovations in the urban context (pp. 3-18). Cham: Springer. https://doi. org/10.1007/978-3-319-21551-8_1

Bridenthal, R. (1994). Die Rolle der organisierten Landfrauen bei der konservativen Mobilmachung in der Weimarer Republik [The role of organized rural women in conservative mobilization in the Weimar Republic]. Feministische Studien, 12(1), 110-121. https://doi.org/10.1515/ fs-1994-0112

Bürgerbusverein Badbergen e.V. (n.d.). Über uns—Entstehung [About us—Formation]. Retrieved from https://www.buergerbus-badbergen.de/ueber-uns-entstehung/

Cajaiba-Santana, G. (2014). Social innovation: Moving the field forward: A conceptual framework. Technological Forecasting and Social Change, 82, 42-51. https://doi.org/10.1016/j. techfore.2013.05.008

Calhoun, C. (2011). Civil society and the public sphere. In M. Edwards (Ed.), The Oxford handbook of civil society (pp. 311-323). Oxford, UK: Oxford University Press. https://doi.org/10.1093/ oxfordhb/9780195398571.013.0025

Christmann, G. B. (2019). Innovationen in ländlichen Gemeinden [Innovations in rural communities]. In W. Nell \& M. Weiland (Eds.), Dorf: Ein interdisziplinäres Handbuch (pp. 235-240). Berlin: J.B. Metzler. https://doi.org/10.1007/978-3-476-05449-4

Christmann, G. B. (2020a). Introduction: Struggling with innovations: Social innovations and conflicts in urban development and planning. European Planning Studies, 28, 423-433. https://doi. org/10.1080/09654313.2019.1639396

Christmann, G. B. (2020b). Soziale Innovationen in ländlichen Räumen [Social innovations in rural areas]. In C. Krajewski \& C.-C. Wiegandt (Eds.), Land in Sicht: Ländliche Räume in Deutschland: zwischen Prosperität und Peripherisierung (pp. 228-239). Bonn: Bundeszentrale für Politische Bildung.

Christmann, G. B., Ibert, O., Jessen, J., \& Walther, U.-J. (2020). Innovations in spatial planning as a social process-phases, actors, conflicts. European Planning Studies, 28, 496-520. https:// doi.org/10.1080/09654313.2019.1639399

DiMaggio, P. J., \& Powell, W. W. (1983). The iron cage revisited: Institutional isomorphism and collective rationality in organizational fields. American Sociological Review, 48, 147-160. https://doi.org/10.2307/2095101

DLV e.V. (2018). Jahresbericht 2017: Stimmgewaltig. Mitbestimmend. Mittendrin [Annual Report 2017: Loud voiced. Participating. In the middle]. Retrieved from https://www.landfrauen.info/ fileadmin/Redaktion/PDF/Publikationen/2018_dlv_Jahresbericht_2017_web.pdf

DLV e.V. (2019). Jahresbericht 2018: Vertrauen festigen: Veränderung wagen [Annual Report 2018: Build trust: Dare to change]. Retrieved from https://www.landfrauen.info/fileadmin/ Redaktion/PDF/Publikationen/2018_LandFrauen_dlv_Jahresbericht_Webversion.pdf 
DLV e.V. (2020a). Jahresbericht 2019: Landfrauen zeigen Flagge [Annual Report 2019: LandFrauen plant their flag]. Retrieved from https://www.landfrauen.info/fileadmin/Redaktion/ PDF/Publikationen/Jahresbericht_dlv_2019.pdf

DLV e.V. (2020b). Aus Liebe zum Land: Wofür aktive LandFrauen stehen: Ziele und Botschaften [What active LandFrauen stand for: Goals and messages]. Retrieved from https://www.landfrauen.info/verband/ziele-botschaften

Domanski, D., Howaldt, J., \& Kaletka, C. (2020). A comprehensive concept of social innovation and its implications for the local context—on the growing importance of social innovation ecosystems and infrastructures. European Planning Studies, 28, 454-474. https://doi.org/10.108 0/09654313.2019.1639397

Ebeling, B. (2017). Akteure der Landwirtschaft in Leader-Aktionsgruppen: Untersuchungen zur Teilnahmemotivation vor dem Hintergrund sozio-kultureller Fragmentierung [Agricultural actors in Leader action groups: Studies on the motivation to participate against the background of socio-cultural fragmentation] (Doctoral dissertation). Georg-AugustUniversität Göttingen, Germany. Retrieved from https://alr-hochschulpreis.de/sites/default/ files/publikationen2020-04/2017-A-Ebeling_Akteure-der-Landwirtschaft-in-LeaderAktionsgruppen.pdf

Füg, F., \& Ibert, O. (2020). Assembling social innovations in emergent professional communities: The case of learning region policies in Germany. European Planning Studies, 28, 541-562. https://doi.org/10.1080/09654313.2019.1639402

Gailing, L., \& Ibert, O. (2016). Schlüsselfiguren: Raum als Gegenstand und Ressource des Wandels [Key figures: Space as an object and resource of change]. Raumforschung und Raumordnung, 74, 391-403. https://doi.org/10.1007/s13147-016-0426-3

Glückler, J., \& Bathelt, H. (2017). Institutional context and innovation. In H. Bathelt, P. Cohendet, S. Henn, \& L. Simon (Eds.), The Elgar companion to innovation and knowledge creation (pp. 121-137). Cheltenham: Edward Elgar. https://doi.org/10.4337/9781782548522.00015

Glückler, J., Herrigel, G., \& Handke, M. (2020). On the reflexive relations between knowledge, governance, and space. In J. Glückler, G. Herrigel, \& M. Handke (Eds.), Knowledge for governance (pp. 1-21). Knowledge and Space: Vol. 15. Cham: Springer. https://doi. org/10.1007/978-3-030-47150-7_1

Grabher, G., \& Ibert, O. (2014). Distance as asset? Knowledge collaboration in hybrid virtual communities. Journal of Economic Geography, 14(1), 97-123. https://doi.org/10.1093/jeg/lbt014

Growe, A., \& Henn, S. (2020). Temporäre räumliche Nähe-Akteure, Orte und Interaktionen [Temporary proximity - actors, places, and interactions]. Raumforschung und Raumordnung, 78(1), 1-3. https://doi.org/10.2478/rara-2020-0004

Habermas, J. (1989). The structural transformation of the public sphere: An inquiry into a category of bourgeois society [Strukturwandel der Öffentlichkeit: Untersuchungen zu einer Kategorie der bürgerlichen Gesellschaft] (T. Burger \& F. Lawrence, Trans.). Cambridge, MA: The MIT Press. (Original work published 1962)

Helmle, S. (2009). „Wie man sich durchbeißen kann“—Landfrauenarbeit in Bayern nach 1945 ["How to break through"-Farm women and their organization in Bavaria after 1945]. In T. Oedl-Wieser \& I. Darnhofer (Eds.), Gender Issues in der Landwirtschaft (pp. 27-42). Jahrbuch der Österreichischen Gesellschaft für Agrarökonomie: Vol. 18(2). Vienna: Facultas.

Howaldt, J., \& Schwarz, M. (2010). Social innovation: Concepts, research fields and international trends. Studies for Innovation in a Modern Working Environment: Vol. 5. Aachen, Germany: RWTH Aachen University.

Howaldt, J., \& Schwarz, M. (2016). Social innovation and its relationship to social change: Verifying existing social theories in reference to social innovation and its relationship to social change. TU Dortmund University. Retrieved from https://eldorado.tu-dortmund.de/bitstream/2003/35207/1/SI-DRIVE-D1-3-Social-Change-final-260416.pdf 
Howaldt, J., \& Schwarz, M. (2018). Soziale Innovation [Social innovation]. In B. Blättel-Mink, I. Schulz-Schaeffer, \& A. Windeler (Eds.), Handbuch Innovationsforschung (pp. 1-17). Wiesbaden: Springer.

Icken, A. (2002). Der deutsche Frauenrat: Etablierte Frauenverbandsarbeit im gesellschaftlichen Wandel [The German Women's Council: Established women's association work in social change]. Opladen: Leske \& Budrich.

Jackisch, C., Berg, C., Bohnenkamp, H., Seifart, U., Serve, H., \& Maulbecker-Armstrong, C. (2020). Präventionsprogramme der Landeskrebsgesellschaften [Prevention programs of the regional cancer societies]. Forum, 35(1), 24-30. https://doi.org/10.1007/s12312-020-00747-6

Kaschuba, G. (1996). Bildungsprozesse in den Biographien von Frauen in ländlichen Regionen. REPORT Literatur- und Forschungsreport Weiterbildung, 37/1996, 53-66. Retrieved from http://www.die-bonn.de/id/1674

Kistemann, E. (2003). Landfrauen in Nordrhein-Westfalen als Gästeführerinnen. Kulturlandschaftliche Aspekte in der Ausbildung [LandFrauen in North Rhine-Westphalia as tour guides. Cultural landscape aspects in training]. Kulturlandschaft, 13(1/2), 29-32. Retrieved from https://www.kulturlandschaft.org/publikationen/kulturlandschaft-1/2003_01-02.pdf

Krambach, K. (2005). Vorwort [Preface]. In Rosa-Luxemburg-Stiftung (Ed.), Landfrauentreibende Kraft der Dorfentwicklung: Dokumentation einer Tagung (pp. 4-8). Retrieved from http://www.rosalux.de/fileadmin/rls_uploads/pdfs/Themen/Wirtschaft/Landfrauen-3. Juni05.pdf

Krieg, B. (1999). Landfrauenbewegung im Wandel: Ziele, Inhalte, Herausforderungen und Perspektiven [The changing LandFrauen movement: Goals, content, challenges and perspectives]. In H. Heidrich (Ed.), Frauenwelten: Arbeit, Leben, Politik und Perspektiven auf dem Land (pp. 79-98). Bad Windsheim: Fränkisches Freilandmuseum.

Lambooy, J. G. (2010). Knowledge transfers, spillovers and actors: The role of context and social capital. European Planning Studies, 18(6), 873-891. https://doi.org/10.1080/09654311003701407

Lave, J., \& Wenger, E. (1991). Situated learning: Legitimate peripheral participation. Learning in Doing: Social, Cognitive, and Computational Perspectives: Vol. 3. Cambridge, UK: Cambridge University Press.

LFV Mecklenburg-Vorpommern e.V. (2020). Trägerschaft der Kita Kinderland in Friedland [Trusteeship of the Kinderland day care center in Friedland]. Retrieved from https://landfrauenmv.de/der-verband/unsere-kita

LFV Schleswig-Holstein e.V. (2020). LandFrauen-Archiv Molfsee: Die Geschichte der Frauen sichtbar machen [LandFrauen-Archiv Molfsee: Making the history of women visible]. Retrieved from https://landfrauen-sh.de/wir/landfrauen-archiv-molfsee/

LFV Württemberg-Baden e.V. (2020a). Leitthema 2020-2023-Grenzen-los digital!? [Leading theme 2020-2023-Digital without limits!?]. Retrieved from https://landfrauen-bw.de/ bildung/leitthema-2020-2023/

LFV Württemberg-Baden e.V. (2020b). Seniorenbotschafterinnen für neue Medien [Senior ambassadors for new media]. Retrieved from https://landfrauen-bw.de/projekte/ senioren-technik-botschafterin/

Lütt, S. (2007). Wiederansiedlung von 60 Wildpflanzenarten in Schleswig-Holstein: Das Jubiläumsprojekt des LandFrauen Verbandes [Resettlement of 60 wild plant species in Schleswig-Holstein: The anniversary project of the LandFrauen association]. Kieler Notizen zur Pflanzenkunde, 35, 60-71. Retrieved from https://www.zobodat.at/pdf/Kieler-Notizen-zurPflanzenkunde_35_0060-0071.pdf

Lux, T. (2020). Volkshochschulen in der Bundesrepublik Deutschland 2018 in Zahlen: Zahlen in Kürze [Adult education centers in the Federal Republic of Germany 2018 in figures: Numbers in brief]. Retrieved from http://www.die-bonn.de/doks/2020-volkshochschule-statistik-02.pdf

Markt-Treff Schleswig-Holstein. (n.d.). MarktTreff: Viele Angebote unter einem Dach [MarktTreff: Many offers under one roof]. Retrieved from https://markttreff-sh.de/de/markttreff-angebot

Mayring, P. (2015). Qualitative Inhaltsanalyse: Grundlagen und Techniken [Qualitative content analysis: Theoretical background and procedures] (12th ed.). Weinheim: Beltz. 
Meusburger, P. (2008). The nexus between knowledge and space. In P. Meusburger, M. Welker, \& E. Wunder (Eds.), Clashes of knowledge: Orthodoxies and heterodoxies in science and religion (pp. 35-90). Knowledge and Space: Vol. 1. Dordrecht: Springer. https://doi. org/10.1007/978-1-4020-5555-3

Moulaert, F., \& MacCallum, D. (2019). Advanced introduction to social innovation. Cheltenham: Edward Elgar.

Moulaert, F., MacCallum, D., \& Hillier, J. (2013). Social innovation: Intuition, precept, concept, theory and practice. In F. Moulaert, D. MacCallum, A. Mehmood, \& A. Hamdouch (Eds.), The international handbook on social innovation: Collective action, social learning and transdisciplinary research (pp. 13-25). Cheltenham: Edward Elgar. https://doi. org/10.4337/9781849809993.00011

Mulgan, G., Tucker, S., Ali, R., \& Sanders, B. (2007). Social innovation: What it is, why it matters and how it can be accelerated. Skoll Centre for Social Entrepreneurship. Retrieved from https://wayback.archive-it.org/org-467/20190705170110/http://eureka.sbs.ox.ac.uk/761/1/ Social_Innovation.pdf

Müller, F. C., \& Ibert, O. (2015). (Re-)sources of innovation: Understanding and comparing time-spatial innovation dynamics through the lens of communities of practice. Geoforum, 65, 338-350. https://doi.org/10.1016/j.geoforum.2014.10.007

Niedersächsischer LandFrauenverband Hannover. (2020). Pressemitteilung: „CoWork: für dichfürs Land! " [Press release: "CoWork: for you—for the country!"]. Retrieved from https:// landfrauen-nlv.de/news/detail/news/pressemitteilung-cowork-fuer-dich-fuers-land.html

Priemer, J., Krimmer, H., \& Labigne, A. (2017). ZiviZ-Survey 2017: Vielfalt verstehen: Zusammenhalt stärken [Understand diversity: Strengthen cohesion: ZiviZ survey 2017]. Essen: Edition Stifterverband. Retrieved from https://www.ziviz.info/ziviz-survey-2017

Punstein, A. M., \& Glückler, J. (2020). In the mood for learning? How the thought collectives of designers and engineers co-create innovations. Journal of Economic Geography, 20(2), 543-570. https://doi.org/10.1093/jeg/lbz019

Putnam, R. D. (2000). Bowling alone: America's declining social capital. In L. Crothers \& C. Lockhart (Eds.), Culture and politics: A reader (pp. 223-234). New York: Palgrave Macmillan. https://doi.org/10.1007/978-1-349-62965-7_12

Putzing, M. (2003). Neue Erwerbsperspektiven für Frauen auf dem Lande: Ergebnisse eines innovativen Modellprojektes. Der Kritische Agrarbericht, 2003, 58-62. Retrieved from http:// make-sense.org/fileadmin/Daten-KAB/KAB-2003/Putzing.pdf

Richter, R. (2019). Rural social enterprises as embedded intermediaries: The innovative power of connecting rural communities with supra-regional networks. Journal of Rural Studies, 70, 179-187. https://doi.org/10.1016/j.jrurstud.2017.12.005

Rosa-Luxemburg-Stiftung. (2005). Landfrauen—treibende Kraft der Dorfentwicklung: Dokumentation einer Tagung [Rural women-driving force in village development: Documentation of a conference]. Retrieved from http://www.rosalux.de/fileadmin/rls_uploads/ $\mathrm{pdfs} /$ Themen/Wirtschaft/Landfrauen-3.Juni05.pdf

Rudolph, C., \& Schirmer, U. (2004). Gestalten oder verwalten? Kommunale Frauenpolitik zwischen Verrechtlichung, Modernisierung und Frauenbewegung [Design or manage? Local women's politics between juridification, modernization and women's movement]. Wiesbaden: VS Verlag für Sozialwissenschaften. https://doi.org/10.1007/978-3-663-01245-0

Rutten, R. (2017). Beyond proximities: The socio-spatial dynamics of knowledge creation. Progress in Human Geography, 41(2), 159-177. https://doi.org/10.1177/0309132516629003

Sawahn, A. (2009). Die Frauenlobby vom Land: Die Landfrauenbewegung in Deutschland und ihre Funktionärinnen 1898 bis 1948 [The women's lobby from the country: Landfrauen movement in Germany and its functionaries from 1898 to 1948]. Frankfurt: DLG.

Sawahn, A. (2012). „Tradition mit frischem Wind“: Weibliches Selbstbildnis als Machtfaktor der Landfrauenvereine ["Tradition with a breath of fresh air": Female self-portrait as a power factor in LandFrauen associations]. In D. Münkel \& F. Uekötter (Eds.), Das Bild des Bauern: 
Selbst- und Fremdwahrnehmungen vom Mittelalter bis ins 21. Jahrhundert (pp. 147-178). Göttingen: Vandenhoeck \& Ruprecht.

Schermer, M., \& Kroismayr, S. (2020). Social innovation in rural areas. Österreichische Zeitschrift für Soziologie, 45(1), 1-6. https://doi.org/10.1007/s11614-020-00398-w

Schumpeter, J. (1912). Theorie der wirtschaftlichen Entwicklung: Eine Untersuchung über Unternehmergewinn, Kapital, Kredit, Zins und den Konjunkturzyklus [The theory of economic development: An inquiry into profits, capital, credit, interest, and the business cycle]. Leipzig: Duncker \& Humblot.

Schumpeter, J. (1942). Capitalism, socialism, and democracy. New York: Harper \& Brothers.

Schwarz, C. (1990). Die Landfrauenbewegung in Deutschland: Zur Geschichte einer Frauenorganisation unter besonderer Berücksichtigung der Jahre 1898 bis 1933 [The Landfrauen movement in Germany: On the history of a women's organization with special consideration of the years 1898 to 1933]. Studien zur Volkskultur in Rheinland-Pfalz: Vol. 9. Mainz: Gesellschaft für Volkskunde in Rheinland-Pfalz.

Suarsana, L. (2017). Die LandFrauenorganisationen und ihr lokales Engagement im Spiegel der Regionalentwicklung [The German Country Women's Associations and their civic engagement in the light of regional development]. Raumforschung und Raumordnung, 75(6), 527-542. https://doi.org/10.1007/s13147-017-0502-3

Warren, M. E. (2001). Democracy and association. Princeton, NJ: Princeton University Press.

Wendt, W. R. (2016). Soziale Innovationen-Innovation des Sozialen: Begriff und Geschäft der Neuerung im Kontext der Sozialwirtschaft [Social innovations-innovation of the social: Concept and business of innovation in the context of the social economy]. Sozialer Fortschritt, 65(1/2), 10-16. http://www.jstor.org/stable/45018150

Wenger, E. (1998). Communities of practice: Learning, meaning, and identity. Cambridge, UK: Cambridge University Press.

Zapf, W. (1989). Über soziale Innovationen [On social innovations]. Soziale Welt, 40(1/2), 170-183. http://www.jstor.org/stable/40878048

Zimmer, A. E. (2007). Vereine-Zivilgesellschaft konkret [Associations-civil society concrete] (2nd ed.). Grundwissen Politik: Vol. 16. Wiesbaden: VS Verlag für Sozialwissenschaften. https://doi.org/10.1007/978-3-531-90626-3

Open Access This chapter is licensed under the terms of the Creative Commons Attribution 4.0 International License (http://creativecommons.org/licenses/by/4.0/), which permits use, sharing, adaptation, distribution and reproduction in any medium or format, as long as you give appropriate credit to the original author(s) and the source, provide a link to the Creative Commons license and indicate if changes were made.

The images or other third party material in this chapter are included in the chapter's Creative Commons license, unless indicated otherwise in a credit line to the material. If material is not included in the chapter's Creative Commons license and your intended use is not permitted by statutory regulation or exceeds the permitted use, you will need to obtain permission directly from the copyright holder.

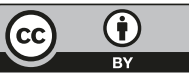

